\title{
RELIGIÃO E RELIGIOSIDADES NO BRASIL: NOVOS ESTUDOS E ABORDAGENS HISTORIOGRÁFICAS
}

VICTOR AUGUSTO MENDONCA GUASTI* UNIVERSIDADE FEDERAL DO ESPÍRITO SANTO VITÓRIA - ESPÍRITO SANTO - BRASIL

\begin{abstract}
SANTIROCCHI, Ítalo Domingos; FERREIRA, Marcia Milena Galdez; RESENHA NERIS, Wheriston Silva (Org.). Religiões e Religiosidades no Brasil: História, Historiografia e Ensino. São Luís: Editora UEMA, 2018. 421p.
\end{abstract}

Religiões e Religiosidades no Brasil: História, Historiografia e Ensino é uma coletânea de artigos organizados por Ítalo Domingos Santirocchi, Marcia Milena Galdez Ferreira e Wheriston Silva Neris, que tem por objetivo apresentar resultados de pesquisas desenvolvidas em diversas regiões do país por autores em diferentes estágios de maturação e com diversas concepções teóricas e metodológicas, mas com objetos de estudos comuns: religiões e religiosidades. A obra conta com quatorze artigos, divididos em quatro seções. A primeira parte trata da relação entre a religião, a política e o poder; a segunda reflete sobre as memórias e representações religiosas; a terceira, por sua vez, reflete sobre a religião, trajetórias e narrativas bibliográficas; e, por fim, a quarta parte contempla considerações sobre a religião, as religiosidades e o ensino destas.

O artigo que abre a coletânea foi escrito pelos autores Ernesto Seidl e Wheriston Silva Neris e tem por título: Por uma sócio-história dos imbricamentos entre os domínios religioso e político. O texto faz um resgate histórico do processo de laicização da política, mostrando que, na separação entre Igreja e Estado, este se utilizou dos ritos religiosos para construir sua própria liturgia, rica de simbolismos que prestavam culto à nação, ao governo e ao sistema político, sendo, portanto, um mecanismo de convencimento e domínio da população. No texto há também a reflexão sobre a má demarcação das fronteiras entre o religioso e o político no Brasil, fruto de uma herança da dominação católica da sociedade, enquanto religião oficial da colônia e Império, bem como apoiadora de alguns governos no regime republicano. Os autores

\footnotetext{
* Mestrando do Programa de Pós-graduação em História da Universidade Federal do Espírito Santo. Membro do Laboratório de História, Poder e Linguagens (UFES), Bolsista da Capes. E-mail: guasti.victor@gmail.com.
} 
apresentam uma série de dados e argumentos que comprovam ser uma característica política de nosso tempo a aliança entre as Igrejas Evangélicas e determinados grupos políticos. Essa aliança tem por objetivo garantir que estes grupos permaneçam no poder impondo sua pauta conservadora e, por vezes, fundamentalistas a toda sociedade brasileira. Por essa razão, as igrejas trabalham promovendo o nome de seus pares e cooptando votos em meio aos seus fiéis. Os autores também realizam um profícuo resgate do processo histórico pelo qual passou as relações da Igreja Católica com a sociedade, em especial a partir dos anos 1960, no contexto de ditadura e surgimento da teologia da libertação. Porém, como afirmam estes, a Igreja Católica constituiu uma militância política indireta, com maior participação em movimentos sociais, enquanto os neopentecostais tiveram maior êxito em aproximar-se dos partidos e alcançar cargos eletivos.

O texto que segue, A questão religiosa no reinado de D. José I em Portugal, de autoria de Ítalo Domingos Santirocchi, busca analisar algumas das principais características das tensões entre o estado moderno e a Igreja Católica, partindo da ideia de que a "Questão Religiosa" foi um processo de longa duração. Analisando as tensões entre os regalistas e os curalistas, o autor utiliza-se do regalismo pombalino para exemplificar essa disputa dentro do Estado Nacional Moderno. Analisando as reformas implementadas por Pombal, no que tange as relações entre o Estado e a Igreja, o autor mostra que todas as medidas tomadas foram com o intuito de enquadrar a Igreja ao poder régio, diminuindo a influência eclesiástica sobre o reino, com o objetivo de modernizar, à luz iluminista, todo império português. Contudo, conclui o autor, Pombal, diferente dos iluministas mais radicais, não buscou a total separação entre a Igreja e o Estado, mas a manutenção dessa união, com o domínio do poder real sobre o papal.

Marcus Caetano Domingos, no capítulo intitulado Sotainas constitucionais: religião e política na comarca de Paracatu - 1821-22, a partir da micro-história, apresenta a trajetória e as relações clientelares do cônego Hermógenes Casimiro de Araújo Brunswik. Analisando o processo da eleição de Hermógenes para deputado nas Cortes Gerais, em pleito avulso e paralelo ao que ocorreu na Província de Minas Gerais, o autor observa as contradições internas do processo político brasileiro e como o clero se relacionava com e neste processo. O texto demonstra que, mesmo sendo um padre do baixo clero, Hermógenes conseguiu alcançar destaque na vida política e pública da sua região, ocupando posições civis e militares de 
destaque e exercendo outros ofícios além do sacerdócio. Vindo de uma família com posses, não conseguiu atingir o status políticos de outros clérigos provenientes da Diocese de São Paulo, mas conquistou prestígio e respeito na região de Paracatu. Com a análise da trajetória do padre Hermógenes, Marcus Domingos apresenta como se dava a participação do clero na vida pública e política dos rincões brasileiros no período de formação do Estado Imperial, bem como os projetos pessoais e as disputas políticas em que se envolviam.

O capítulo escrito por Fernando Arthur de Freitas Neves, com o título Sobre o Ultramontanismo: os Bispos do oitocentos e a Romanização, apresenta as reformas realizadas pela Igreja Católica no Brasil, na segunda metade do século XIX, a partir do episcopado de Dom Macedo Costa à frente da Diocese do Pará. Na luta entre as tentativas conservadoras da Igreja e os projetos progressistas dos liberais e a oposição de republicanos, maçons e protestantes, D. Macedo, ao assumir o pastoreio da Diocese do Pará, buscou implementar as reformas romanizadoras, típicas do movimento ultramontano. O autor discute a questão religiosa que ocorreu no Brasil em 1872, trazendo suas motivações e consequências, bem como traça um panorama sobre as reformas educacionais que ocorreram nos seminários. Além disso, também argumenta sobre a posição da Igreja diante da escravidão no Brasil, problematizando sobre a falta de um posicionamento oficial de contrariedade ao sistema escravagista, a partir do fato de a Igreja não possuir uma organização centralizada e forte, e pela falta de autonomia do clero diante da dependência proveniente do padroado.

Mudando o foco para o protestantismo, Elba Fernanda Marques Mota, com seu texto Para onde vamos? Construção do discurso moral e teológico do fiel e eleitor Assembleiano na sociedade brasileira, traz uma reflexão sobre a participação das Igrejas evangélicas no processo eleitoral brasileiro, dando ênfase à Assembleia de Deus. O texto, analisando publicações periódicas vinculadas à igreja, mostra que foi na década de 1970, em meio as diversas mudanças políticas e econômicas pelas quais passava o Brasil, que a Assembleia de Deus mudou o seu entendimento sobre a participação de seus fiéis na política. A autora ainda discorre sobre como o fundamentalismo religioso pentecostal, de origem norte-americana, foi o motivador para o envolvimento da religião com política.

A segunda parte do livro começa com o artigo de Edianne dos Santos Nobre, denominado Corpos santos e histéricos: os fenômenos de Juazeiro nos periódicos do século 
XIX. A autora traça uma discussão sobre o fenômeno religioso que ocorria com o Padre Cícero Romão e suas "beatas", a partir de conceitos típicos da História Cultural. Partindo da historiografia das religiões e das religiosidades, a autora propõe analisar o caso do sangramento da hóstia na boca da beata Maria de Araújo, na contramão da história oficial que coloca o Padre Cícero Romão como o protagonista. Para tal, o texto parte das matérias vinculadas nos jornais do período, analisando os escritos pró e contra a beata e o suposto milagre. Por fim, o texto também discute sobre o ressurgimento do nome da beata na imprensa e no imaginário popular, a partir da descoberta de um pano que supostamente secou o sangue que escorreu de sua boca em um dos milagres.

Maria Aparecida Corrêa Custódio, com o capítulo Fundação da Congregação das Irmãs Missionárias Capuchinhas: entre as tensões e as contradições da missão indígena no Maranhão, discute a formação deste grupo religioso feminino genuinamente brasileiro e o seu objetivo de educar as índias. Discorrendo sobre a missão dos frades capuchinos italianos no Maranhão, que tinha por objetivo civilizar os índios que habitavam o território, a autora narra o Massacre de Alto Alegre e como este evento impulsionou a fundação da congregação feminina no Brasil.

O capítulo intitulado Um novo jeito de ser Igreja nos ditames da ditadura: a experiência de freis franciscanos na luta pela terra no médio Mearim - MA, escrito por Jaciara Leite Frazão, discute a atuação dos frades franciscanos oriundos da Alemanha na luta campesina dos anos de 1960 e 1970. Inspirados pela Teologia da Libertação, os frades lutavam junto aos posseiros de terra, em sua maioria migrantes do semiárido nordestino, contra o avanço dos latifúndios e da grilagem de terras. A Igreja Católica, junto a seus movimentos e organizações, em especial a Comissão Pastoral da Terra, se tornou uma aliada na luta pelas terras. Utilizando-se do diário de missão do Frei Adolfo Temme, e de jornais da época, a autora busca demonstrar a realidade local do período e como se dava a ação do sacerdote. O estudo da fonte também apresenta como os leigos se organizavam e utilizavam da estrutura -mesmo que deficitária - da Igreja, para lutar por seus direitos e pela possa da terra.

Seguindo a mesma linha, Marcia Milena Galdez Ferreira, ao escrever Luto e luta pela terra no médio Mearim-MA: mediações e traduções através da teologia da libertação, investiga os conflitos pela terra a partir da interpretação da Teologia da Libertação contra a Lei de Terras 
criada em 1969. Utilizando-se das crônicas escritas pelo Frei Adolfo Temme, a autora revela como os textos do frade mostravam os conflitos, a luta pela terra e o cotidiano violento da região, a partir de imagens inspiradas em passagens bíblicas.

A terceira parte do livro começa com o texto $O$ caminho que leva a Deus: a trajetória do padre lazarista Pierre Auguste Chevalier (Ceará, 1831-1901), escrito pela Pryscylla Cordeiro Rodrigues Santirocchi. Nele, a autora refaz a trajetória do padre francês, ultramontano, que exerceu funções diretivas nos seminários da Bahia e do Ceará. Pertencente à Congregação da Missão, o missionário francês chegou a Fortaleza com o objetivo de reformar a Igreja, adequando os seminários à linha de formação tridentina. Sua formação contrastava com o modelo de Igreja luso-brasileira, o que gerou diversos conflitos com a sociedade e o restante do clero local. O modelo de formação rígido que fora imposto pelo padre Chevalier também gerou uma revolta nos seminaristas, fato que levou à sua demissão. Toda trajetória do padre apresentado pela autora evidencia os caminhos de interdependência entre o indivíduo e a sociedade.

O capítulo seguinte, Dimensão histórica e cotidiana das nucleações protestantes pentecostais no Médio Mearim Bacabalense a partir das narrativas biográficas e orais (19301940), foi escrito por Marcos Ferreira Silva. Nele, o autor utiliza os escritos e cartas biográficas de Francisco Assis Gomes e do pastor Boaventura Pereira Sousa. Somadas a outras fontes e uma profícua base teórica, o texto resgata a organização e a ação da igreja pentecostal de Médio Mearim, demonstrando suas configurações socioculturais.

Poliane Pereira Almeida segue a linha do capítulo anterior, apresentando a trajetória e o ministério pastoral do pastor Boaventura Pereira Sousa. Seu texto, Trajetória do Pastor Boaventura Pereira Sousa na Assembleia de Deus de Bacabal-MA (1963 - 1996), resgata a atuação do pastor que construiu o templo central da Assembleia de Deus local e organizou a ação da igreja no local. Além disso, também apresenta como a própria igreja foi se desenvolvendo e se organizando nesse espaço de 35 anos.

Na quarta parte do livro, as discussões sobre religião, religiosidade e ensino começam com o capítulo de autoria de Reinilda de Oliveira Santos, intitulado Educação, relações étnicoraciais e ensino de História: cultura africana e afro-brasileira em códigos legais. Neste texto, 
a autora analisa a trajetória do ensino de cultura africana e afro-brasileira, que está em vigor desde a promulgação da lei $\mathrm{n}^{\circ} 10.639$ de 2003. Seus apontamentos demonstram que existem falhas substanciais no ensino sobre religiosidade afro-brasileira na educação brasileira. Isso porque falta aos docentes formação específica para discutir em sala de aula os encontros e confrontos culturais, os sincretismos e hibridismos, a positivação e a marcação de identidades étnico-religiosas. O texto comprova, a partir da discussão sobre todo o processo de renovação da educação na Nova República, que a inclusão do ensino sobre cultura e religiosidade afrobrasileira foi um grande avanço, mas ainda estamos longe de efetivar sua aplicação. Em especial, pelo fato de a cultura negra ser uma ausência na escola e de não existir muitos manuais didáticos que ajudem na efetivação do ensino de cultura afro e afro-brasileira, sem subjugá-la diante da cultura europeia e livre dos preconceitos que ainda permeiam a sociedade brasileira.

Renata Carvalho Silva encerra a coletânea mantendo-se na linha reflexiva sobre o ensino de religião e religiosidades, analisando o ensino sobre cultura, história e religiosidade indígena. O capítulo intitulado Seria Tupã um deus? Os mitos e o ensino de história e cultura indígena analisa como o ensino ainda é influenciado pela ideia colonizadora, que subjuga a cultura e a religiosidade ameríndia. Analisando monografias que tratam da mitologia dos Tenetehara do Maranhão, a autora comprova que houve avanços na interpretação e no tratamento da cultura indígena, mas que ainda existem muito traços do colonialismo. Analisando os avanços que surgiram a partir da lei $\mathrm{n}^{\mathrm{o}} 11.645$, de 10 março de 2008, que inseriu a obrigatoriedade do ensino de História e Cultura dos Povos Indígenas, a autora afirma que somente com a efetivação da lei será possível vencer a reprodução de preconceitos e processos e compreender verdadeiramente como se deu a construção da nação brasileira. Atingir esse objetivo, no entanto, perpassa pela consolidação de um ensino de religiosidade indígena dentro dos pressupostos e conhecimentos culturais deste grupo, fugindo da reprodução desta religiosidade a partir do entendimento cristão. Logo, é necessário aprender a língua, a cultura e a verdadeira mitologia indígena para que os equívocos deixem de ser ensinados e perpetuados. E isto depende da desconstrução da construção social do índio, da compreensão da pluralidade da cultura nativa e da descolonização do pensamento e do ensino. É somente por esse caminho que poderemos consolidar a noção de sabedoria e conhecimento de mundo dessas sociedades. 
Toda a discussão realizada na coletânea ajuda na compreensão sobre avanços nos estudos acerca da temática religião e religiosidades no Brasil. Do mesmo modo, traz importante reflexão sobre o longo caminho que ainda precisamos percorrer para efetivar um verdadeiro ensino religioso capaz de contemplar as religiosidades afro-brasileiras e ameríndias de forma ampla e sem preconceitos. Por fim, o resgate histórico realizados pelos autores auxiliam a atinar as relações entre religião e poder no Brasil, e estabelecer ligação entre o sagrado e profano na experiência cotidiana. 